В.А. Скибчик', О.С. Пелешко ${ }^{2}$

${ }^{1}$ Львівський національний медичний університет імені Данила Галицького

${ }^{2}$ Комунальне підприємство «Центральна міська лікарня Червоноградської міської ради»

\title{
Когнітивні порушення у пацієнтів з артеріальною гіпертензією: огляд літератури та власний досвід
}

У статті узагальнено дані низки епідеміологічних досліджень щодо проблеми взаємозв'язку між артеріальною гіпертензією (АГ) та когнітивними порушеннями, деменцією. Увласному дослідженні встановлено, що наявність АГ достовірно підвищує частоту розвитку когнітивних порушень в осіб середнього віку (49,8土9,0 року). Обстежено 59 пацієнтів (1-ша група) із АГ II-ІІІ стадії, 2-3 ступеня (середній рівень систолічного та діастолічного артеріально-

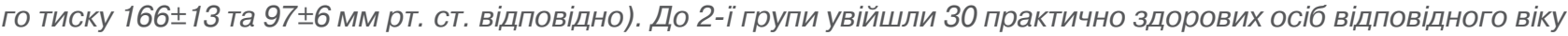
з нормальним рівнем артеріального тиску. Для вивчення когнітивних порушень застосовували нейропсихологічні тести: шкалу оцінки когнітивних функцій лікарем загальної практики (General Practitioner Assessment of Cognition - GPCOG), коротку шкалу оцінки психічного статусу(Mini-Mental State Examination - MMSE), таблиці Шульте. Aналіз результатів показав достовірне погіршення когнітивного статусу у пацієнтів 1-ї групи (MMSE 26,6士1,8; GPCOG

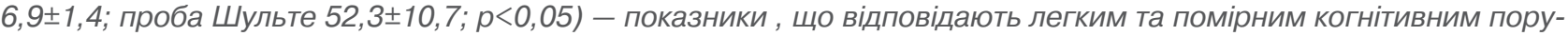

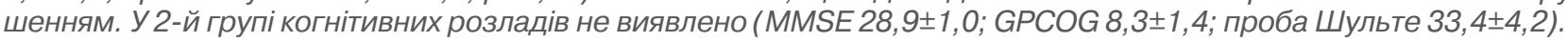

Ключові слова: артеріальна гіпертензія, нейропсихологічні тести, когнітивні порушення, деменція.

\section{Вступ}

Деменція - актуальна медична та соціальна проблема. У світі налічують близько 50 млн людей з деменцією, щороку реєструють близько 10 млн нових випадків захворювання. Згідно з прогнозами, загальна кількість хворих на деменцію становитиме близько 82 млн у 2030 р. і підвищиться майже вдвічі до 2050 р. (WHO, 2017).

Появі деменції завжди передують когнітивні порушення (КП). Так, через 1 рік у 5-15\% пацієнтів із помірними КП виникне деменція (для порівняння - в загальній популяції вірогідність її розвитку становить 1-5\%), через 4 роки таких пацієнтів буде вже $70 \%$, а через 5 років на деменцію страждатимуть 100\% пацієнтів із КП (Larrieu S. et al., 2002).

Найважливішим фактором ризику КП є захворювання серцево-судинної системи, особливо артеріальна гіпертензія (АГ). Субклінічні ураження головного мозку, як органа-мішені при АГ, відзначають у $44 \%$ хворих, що приблизно вдвічі перевищує поширеність ураження серця та нирок (Kearney-Schwartz A. et al., 2009). Одним із проявів такого ураження є КП.

\section{КП при АГ}

Взаємозв'язок між високим артеріальним тиском (АТ) і розладами когнітивних функцій встановлений у багатьох епідеміологічних дослідженнях: The Framingham Heart Study, Hoorn Study, Uppsala Longitudinal Study of Adult Men, ARIC, Honolulu-Asia Aging Study. Результати переконливо продемонстрували, що високий систолічний АТ (САТ) в середині життя прямо корелює з ризиком когнітивного зниження у похилому віці. Підвищення САТ на кожні 10 мм рт. ст. підвищує ризик помірних КП на 7\%, тяжких - на 9\% (Launer L.J. et al., 2000).

G.E. Swan та співавтори (1996) довели, що підвищення як САT, так і діастолічного АТ у середньому віці є предиктором КП через 25 років. За даними L. Kilander та співавторів (1998), КП у віці 70 років безпосередньо пов'язані з підвищеним АТ у віці 50 років. Дослідження включало 999 чоловіків віком 70 років, які перебували на обліку у зв'язку з наявністю кардіоваскулярних факторів ризику з 50-річного віку. Взаємозв'язок між рівнем АТ та КП був найсильніший у нелікованих пацієнтів із АГ. У дослідженні EVA у пацієнтів із середнім віком 65 років після 4-річного спостереження доведено, що ризик КП у 2,8 раза вищий у пацієнтів із АГ порівняно з контрольною групою (Tzourio C. et al., 1999). 668 японських пацієнтів віком 65-79 років були залучені у дослідження Hisayama, що тривало 17 років. Протягом зазначеного періоду у 76 пацієнтів розвинулася судинна деменція. Після вивчення всіх можливих факторів ризику встановлено, що у осіб із АГ I та II стадії ризик розвитку судинної деменції був відповідно у 4,5 та 5,6 раза вищий порівняно з пацієнтами з нормальним АТ (Ninomiya T. et al., 2011).

У дослідженні Women's Health and Aging Study II довели, що підвищений АТ не лише у середньому, але й у старшому віці може спричиняти розвиток КП. У пацієнтів віком $70-75$ років високий пульсовий тиск ( $\geqslant 71$ мм рт. ст.) асоціювався з розладами вербальної пам'яті, тоді як у пацієнтів віком $76-80$ років високий САТ ( $\geqslant 160$ мм рт. ст.) чи пульсовий тиск ( $\geqslant 84$ мм рт. ст.) - 3 порушеннями виконавчих функцій (Yasar S. et al., 2011). За даними ще одного дослідження, що включало 1115 пацієнтів віком >85 років, найгірші показники когнітивних функцій відзначено в осіб із САТ $>165$ або <125 мм рт. ст. порівняно з пацієнтами з САТ 126139 мм рт. ст. (Weidung B. et al., 2016).

Когнітивні функції вивчали також у когорті відносно молодих осіб. Наприклад A. Shehab, A. Abdulle (2011) досліджували вплив АГ «білого халата» та помірної АГ на розвиток КП у пацієнтів середнього віку - 38,2 $\pm 10,8$ року. Аналіз клінічних даних 24 -годинного моніторингу АТ та когнітивного статусу показав зниження когнітивних функцій у пацієнтів із АГ «білого халата» (здебільшого розлади пам'яті) та у осіб із пограничними показниками АТ (здебільшого сповільнена реакція) порівняно з контрольною групою.

Однак деякі дослідники припускають, що розвиток деменції більше пов'язаний з низькими рівнями АТ, особливо у осіб похилого та старечого віку. Так, J.R. Mahoney та співавтори (2010) виявили, що особи віком $>70$ років з нижчим САТ продемонстрували гірші результати когнітивних функцій, ніж особи з нормальним і дещо підвищеним АТ. Також у жителів Австралії, середній вік яких становив 101 рік, низький САТ та низький пульсовий тиск асоціювалися з гіршим когнітивним та функціональним статусом (Richmond R. et al., 2011).

\section{Вплив антигіпертензивної терапії}

\section{на когнітивні функції}

На сьогодні є достатньо даних щодо здатності антигіпертензивної терапії знижувати ризик розвитку нових випадків КП (Levi Marpillat N. et al., 2013).

Результати досліджень PROGRESS (Perindopril Protection Against Recurrent Stroke Study) та Syst-Eur (Systolic Hypertension in Europe) продемонстрували значне покращення когнітивних 
функцій на фоні прийому антигіпертензивних препаратів. Зокрема у дослідженні Syst-Eur відзначено зменшення на 50\% частки випадків розвитку деменції у пацієнтів віком $>60$ років, які тривало застосовували медикаменти (Forette F. et al., 2002). Згідно з даними метааналізу 12 клінічних випробувань, в яких порівнювали вплив різних класів антигіпертензивних препаратів на розвиток та прогресування деменції, ризик розвитку КП на 9\% нижчий в осіб, які застосовують антигіпертензивну терапію, незалежно від класу препаратів (Levi Marpillat N. et al., 2013). Проте блокатори рецепторів ангіотензину II показали найкращі результати в поліпшенні когнітивних функцій (зокрема покращення сприйняття, пам'яті та концентрації уваги) порівняно з плацебо та були ефективнішими, ніж блокатори $\beta$-адренорецепторів, діуретики та інгібітори ангіотензинперетворювального ферменту (Hajjar I. et al., 2002; Fogari R. et al., 2004; Hanon O. et al., 2008).

Але в науковій літературі $€$ й суперечливі відомості. Зокрема, згідно з результатами метааналізу, у 15936 пацієнтів із АГ за відсутності об'єктивно діагностованих цереброваскулярних захворювань не виявлено переконливих доказів того, що зниження АТ в похилому віці зменшує вірогідність розвитку деменції або КП (McGuinness B. et al., 2009). У дослідженні TRANSCEND, яке охопило 5926 пацієнтів, аналізували ефект прийому телмісартану порівняно з плацебо. У дослідженні, окрім кардіоваскулярних подій, оцінювали КП. Проте різниці у зниженні когнітивних функцій між групами не виявлено (Anderson C. et al., 2011).

Хоча оптимальні рівні АТ для підтримки ідеальної вікової психічної діяльності ще не встановлені, в нових рекомендаціях Європейського товариства кардіологів/Європейського товариства з артеріальної гіпертензії (European Society of Cardiology/ European Society of Hypertension - ESC/ESH) з лікування АГ вказано на доцільність досягнення цільових рівнів САТ у межах 130-139 мм рт. ст. у пацієнтів похилого ( $\geqslant 65$ років) та старечого (>80 років) віку при хорошій переносимості терапії. Лікування пацієнтів старечого віку, а також осіб зі старечою астенією, незалежно від хронологічного віку, слід розпочинати з монотерапії (Williams B. et al., 2018).

Мета дослідження - вивчення поширеності КПу хворих на АГ II-III стадії, 2-3 ступеня.

\section{Об'єкт і методи дослідження}

На базі Комунального підприємства «Центральна міська лікарня Червоноградської міської ради» обстежено 59 пацієнтів

Таблиця 1. Оцінка когнітивних функцій лікарем загальної практики (GPCOG)

\begin{tabular}{|c|c|c|}
\hline Запитання & Бали & $\begin{array}{l}\text { Бали } \\
\text { в нормі }\end{array}$ \\
\hline Iм'я та адреса для подальшого тестування пам'яті & & 1 \\
\hline Я збираюся сказати вам ім'я та адресу. Після того, як я їх & & \\
\hline назву, я хочу, щоб ви повторили їх. Запам'ятайте це ім'я & & \\
\hline та адресу, тому що я збираюся знову їх у вас запитати через & & \\
\hline $\begin{array}{l}\text { декілька хвилин: Петро Сидоренко, вул. Шевченка, 42, Вінни- } \\
\text { ця (дозволяється максимум } 4 \text { спроби) }\end{array}$ & & \\
\hline Орієнтування у часі & & 1 \\
\hline Яка сьогодні дата? (лише чітко) & & \\
\hline Малювання годинника & & 1 \\
\hline $\begin{array}{l}\text { Будь ласка, розмітьте всі числа, щоб вказати години } \\
\text { на циферблаті годинника (важлива правильна відстань). } \\
\text { Будь-ласка, відмітьте стрілками } 10 \text { хвилин } \\
\text { на дванадцяту (11:10) }\end{array}$ & & 1 \\
\hline Інформація & & 1 \\
\hline Чи можете ви розповісти мені щось, що сталося в новинах & & \\
\hline $\begin{array}{l}\text { Нещодавно? («нещодавно» - протягом останнього тижня). } \\
\text { Якщо пацієнт дає загальну відповідь, наприклад «війна», } \\
\text { «багато опадів», запитайте про деталі (зараховується лише } \\
\text { чітка відповідь) }\end{array}$ & & \\
\hline Пам'ять & & 1 \\
\hline $\begin{array}{l}\text { Назвіть ім'я та адресу, які я просив вас запам'ятати» } \\
\text { Петро }\end{array}$ & & \\
\hline Сидоренко & & 1 \\
\hline Шевченка, 42 & & 1 \\
\hline Вінниця & & 1 \\
\hline
\end{tabular}

(середній вік - 49,8 $\pm 9,0$ року) із АГ ІІ-ІІІ стадії (32 $(54,2 \%)$ чоловіки та 27 (45,8\%) жінок) - основна (1-ша) група. До 2-ї (контрольної) групи увійшли 30 практично здорових осіб відповідного віку з нормальним рівнем АТ. У дослідження не включали хворих із гострими порушеннями мозкового кровообігу, черепно-мозковими травмами в анамнезі, гемодинамічно значущим стенозом артерій голови та шиї, онкологічними захворюваннями та осіб, які зловживають алкоголем та/чи наркотичними речовинами.

Усім пацієнтам проведено клініко-анамнестичне обстеження з вимірюванням АТ, лабораторні (рівень загального холестерину, холестерину ліпопротеїдів низької та високої щільності, тригліцеридів, глюкози крові, креатиніну з розрахунком швидкості клубочкової фільтрації, електролітів крові) та інструментальні методи дослідження (добове моніторування АТ, електрокардіографію, ультразвукове дослідження серця).

Для об'єктивізації КП використовували нейропсихологічні тестування: шкалу оцінки когнітивних функцій лікарем загальної практики (General Practitioner Assessment of Cognition - GPCOG) (табл. 1), коротку шкалу оцінки психічного статусу (Mini-Mental

\begin{tabular}{|c|c|}
\hline $\begin{array}{c}\text { Максимальна } \\
\text { оцінка } \\
\text { в нормі, балів }\end{array}$ & $\begin{array}{c}\text { Оцінка } \\
\text { у хворого, } \\
\text { балів }\end{array}$ \\
\hline 10 & \\
\hline 1 & \\
\hline 1 & \\
\hline 1 & \\
\hline 1 & \\
\hline 1 & \\
\hline 1 & \\
\hline 1 & \\
\hline 1 & \\
\hline 1 & \\
\hline 1 & \\
\hline 3 & \\
\hline
\end{tabular}

Оріснтащія. Відповісти на запитання:

Який зараз рік?

Яка зараз пора року?

Яке зараз число?

Який зараз місяць?

Який зараз день тижня?

В якій державі ми знаходимося?

В якій області ми знаходимося?

В якому місті ми знаходимося?

В якій лікарні ми знаходимося?

На якому поверсі (в якій палаті) ми знаходимося? Здатність до обліку

Назвати 3 предмети, не пов'язані між собою за змістом (озеро, стіл, копійка) - по 1 с на кожен. Попросити хворого назвати всі 3 предмети, присуджуючи 1 бал за кожну правильну відповідь. Повторити проби, доки пацієнт не назве всі предмети. Порахувати кількість спроб

\section{5 Увага та рахування}

Серія 3 «сімок». Попросити пацієнта віднімати по 7 , починаючи зі 100 - 1 бал за кожну правильну відповідь. Зупинити пацієнта після 5 правильних відповідей $(93,86,79,72,65)$. Якщо паціент не може/не хоче виконати завдання, попросити вимовити слово «Земля» у зворотному порядку. Число балів відповідає кількості букв, названих у правильному порядку Пам'ять

Попросити пригадати найменування 3 предметів,

3 названих раніше, - 1 бал за кожну правильну відповідь

2 Мова

Найменування: показати олівець та годинник, попросити пацієнта назвати їх

Повторення

Попросити пацієнта повторити скоромовку «Ніяких якщо та/або але» (або іншу). Допускається тільки одна спроба

3 Попросити виконати 3-етапну команду:

Візьміть аркуш паперу, складіть його навпіл та покладіть на підлогу - 1 бал за кожну вірно виконану дію

Читання

Попросити пацієнта прочитати «Закрийте очі» та виконати це

Письм0

Попросити пацієнта самостійно написати просте речення

Копіювання

Попросити пацієнта скопіювати намальовані п'ятикутники, що перетинаються. Повинні бути скопійовані всі 10 кутів та 2 повинні перетинатися

29-30 балів - відсутність КП, 28-27 балів - легкі КП, 24-26 балів - помірні КП, 20-23 балів - початкова стадія деменції, <20 балів - виражена деменція. 
Таблиця 3. Оцінка когнітивних функцій у хворих на АГ

\begin{tabular}{|c|c|c|c|c|c|c|}
\hline \multirow[b]{2}{*}{ Шкала } & \multicolumn{3}{|c|}{ Основна група ( $n=59)$} & \multicolumn{3}{|c|}{ Контрольна група (n=30) } \\
\hline & $\begin{array}{l}\text { Середнє } \\
\text { значення }\end{array}$ & $\begin{array}{l}\text { Медіа- } \\
\text { на }\end{array}$ & $\begin{array}{l}\text { Стандартне } \\
\text { відхилення }\end{array}$ & $\begin{array}{c}\text { Середнє } \\
\text { значення }\end{array}$ & $\begin{array}{c}\text { Меді- } \\
\text { ана }\end{array}$ & $\begin{array}{l}\text { Стандартне } \\
\text { відхилення }\end{array}$ \\
\hline GPCOG & $5,9^{*}$ & $6,0^{*}$ & 1,4 & 8,3 & 8,0 & 0,7 \\
\hline MMSE & $26,6^{*}$ & $27,0^{*}$ & 1,8 & 28,9 & 29,0 & 1,0 \\
\hline Проба Шульте & $52,3^{*}$ & $49,6^{*}$ & 10,7 & 33,4 & 32,7 & 4,2 \\
\hline
\end{tabular}

*Достовірні зміни порівняно з контрольною групою; $p<0,05$.

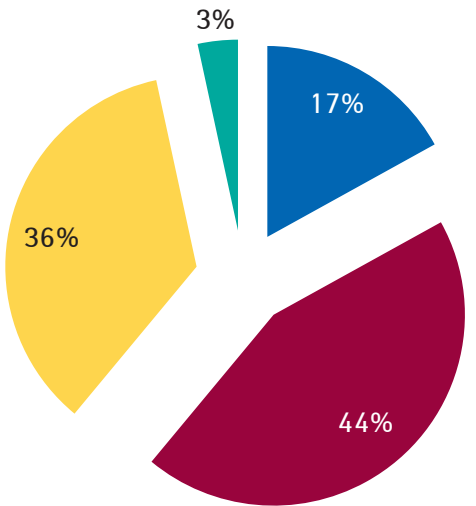

- Норма

- Легкі КП

Помірні КП

п Деменція

Рис. 1. Частота виявлення КП різного ступеня тяжкості у пацієнтів із АГ за шкалою MMSE

State Examination - MMSE) (табл. 2). Стійкість уваги та швидкість сенсомоторних реакцій оцінювали за допомогою таблиць Шульте.

Отримані результати обробляли з допомогою програми «Statistica». Вірогідність різниці між середніми кількісними значенням двох вибірок визначали за критерієм Манна - Уїтні.

\section{Результати та їх обговорення}

Тривалість АГ становила в середньому 9, $1 \pm 2,7$ року. Середній рівень САТ становив 166 113 мм рт. ст., діастолічного АТ $97 \pm 6$ мм рт. ст. Антигіпертензивну терапію постійно застосовували 12 (20,3\%), епізодично - 37 (62,7\%), не застосовували взагалі - 10 (17,0\%) пацієнтів. Основними скаргами були: головний біль, запаморочення, шум у вухах та голові, поганий сон, порушення пам'яті та уваги, швидка втома при розумовій працездатності.

Аналіз результатів нейропсихологічних шкал показав достовірне погіршення когнітивного статусу у хворих на АГ (1-ша, основна група), тоді як у групі практично здорових осіб (2-га, контрольна група) КП не відзначено в жодного з учасників (табл. 3).

При цьому у $2(3,4 \%)$ пацієнтів виявлено деменцію легкого ступеня (20-23 бали) за шкалою MMSE, помірні КП (24-26 балів) у 21 (35,6\%), легкі КП (27-28 балів) - у 26 (44,1\%) (рис. 1). Найбільші труднощі у цих пацієнтів виникали при виконанні розділів «Увага та рахунок», «Здатність до обліку», «Пам'ять», «Рахунок» та «Копіювання».

Пацієнти з АГ (1-ша, основна група) потребували достовірно більше часу на виконання завдань за таблицями Шульте. Їхній середній показник тестування становив $52,3 \pm 10,7$ с, тоді як

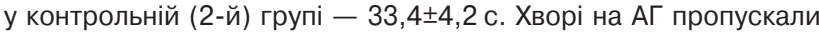
числа, скаржилися на неможливість зосередитися, на швидку втому (рис. 2).

\section{Висновки}

1. АГ - значущий самостійний фактор ризику розвитку нових випадків КП. Зокрема у пацієнтів із АГ ІІ-ІІІ стадії у 44,1\% випадків виявлено легкі КП за шкалою MMSE, у 35,6\% - помірні КП у 3,4\% - деменцію легкого ступеня.

2. Пацієнти середнього віку з АГ повинні регулярно проходити тестування на стан когнітивних функцій, оскільки це може бути раннім предиктором деменції. Шкали GPCOG та MMSE можуть використовувати для скринінгу та клінічної оцінки когнітивних функцій як сімейний лікар, так і лікар-кардіолог.

\section{Список використаної літератури}

Anderson C., Teo K., Gao P. et al. (2011) Renin-angiotensin system blockade and cognitive function in patients at high risk of cardiovascular disease:

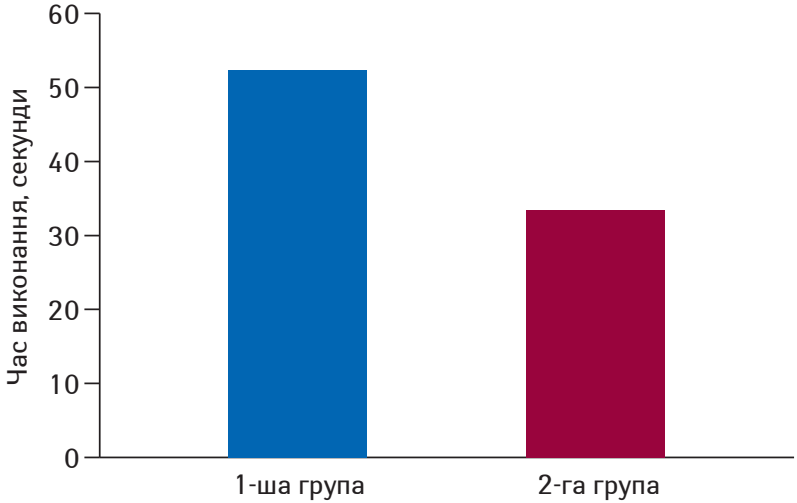

Рис. 2. Порівняння показників швидкості виконання завдань за таблицями Шульте

analysis of data from the ONTARGET and TRANSCEND studies. Lancet Neurol., 10(1): 43-53.

Fogari R., Mugellini A., Zoppi A. et al. (2004) Effects of valsartan compared with enalapril on blood pressure and cognitive function in elderly patients with essential hypertension. Eur. J. Clin. Pharmacol., 59: 863-868.

Forette F., Seux M. L., Staessen J.A. et al. (2002) Systolic hypertension in Europe investigators. The prevention of dementia with antihypertensive treatment: new evidence from the systolic hypertension in Europe (Syst. Eur.) study. Arch. Intern. Med., 162(18): 2046-2052.

Hajjar I., Hart M., Chen Y.L. et al. (2002) Effect of antihypertensive therapy on cognitive function in early executive cognitive impairment: a doubleblind randomized clinical trial. Arch. Intern. Med., 172(5): 442-444.

Hanon 0., Berrou J.P., Negre-Pages L. et al. (2008) Effects of hypertension therapy based on eprosartan on systolic arterial blood pressure and cognitive function: primary results of the Observational Study on Cognitive function And Systolic Blood Pressure Reduction open-label study. J. Hypertens., 26(8): 1642-1650.

Kearney-Schwartz A., Rossignol P., Bracard S. et al. (2009) Vascular structure and function is correlated to cognitive performance and white matter hyperintensities in older hypertensive patients with subjective memory complaints. Stroke, 40: 1229-1236.

Kilander L., Nyman H., Boberg M. et al. (1998) Hypertension is related to cognitive impairment: a 20 -year follow-up of 999 men. Hypertension, 31 : 780-786.

Larrieu S., Letenneur L., Orgogozo J.M. (2002) Incidence and outcome of mild cognitive impairment in a population-based prospective cohort. Neurology, 59: 594-599.

Launer L.J., Ross G.W., Petrovitch H. et al. (2000) Midlife blood pressure and dementia: the Honolulu-Asia aging study. Neurobiol Aging. , 21: 49-55.

Levi Marpillat N., Macquin-Mavier I., Tropeano A.I. et al. (2013) Antihypertensive classes, cognitive decline and incidence of dementia: a network meta-analysis. J. Hypertens., 31(6): 1073-1082.

Mahoney J.R., Verghese J., Goldin Y. et al. (2010) Alerting, orienting, and executive attention in older adults. J. Int. Neuropsychol. Soc., 16(5): 877-889.

McGuinness B., Todd S., Passmore P., Bullock R. (2009) Blood pressure lowering in patients without prior cerebrovascular disease for prevention of cognitive impairment and dementia. Cochrane Database of Systematic Reviews, 4.

Ninomiya T., Ohara T., Hirakawa Y. et al. (2011) Midlife and late-life blood pressure and dementia in Japanese elderly: the Hisayama study. Hypertension, 58(1): 22-28.

Richmond R., Law J., Kay-Lambkin F. (2011) Higher blood pressure associated with higher cognition and functionality among centenarians in Australia. Am. J. Hypertens., 24(3): 299-303.

Shehab A., Abdulle A. (2011) Cognitive and autonomic dysfunction measures in normal controls, white coat and borderline hypertension. BMC Cardiovasc. Disord., 11.

Swan G.E., Carmelli D., La Rue A. (1996) Relationship between blood pressure during middle age and cognitive impairment in old age: The Western Collaborative Group Study. Aging Neuropsychol. Cognit., 3: 241-250.

Tzourio C., Dufouil C., Ducimetiere P. et al. (1999) Cognitive decline in individuals with high blood pressure: a longitudinal study in the elderly. EVA Study Group. Epidemiol. Vasc. Aging Neurol., 53: 1948-1952.

Weidung B., Littbrand H., Nordström P. et al. (2016) The association between SBP and mortality risk differs with level of cognitive function in very old individuals. J. Hypertens., 34(4): 745-752.

WHO (2017) Dementia: fact sheet (https://www.who.int/news-room/factsheets/detail/dementia). 
Williams B., Mancia G., Spiering W. et al. (2018) 2018 ESC/ESH Guidelines for the management of arterial hypertension (https://academic.oup. com/eurheartj/article/39/33/3021/5079119).

Yasar S., Ko J.Y., Nothelle S. et al. (2011) Evaluation of the effect of systolic blood pressure and pulse pressure on cognitive function: the Women's Health and Aging Study II. PLOS One, 6(12) (https://journals.plos.org/plosone/article?id=10.1371/ journal.pone.0027976).

\section{Когнитивные нарушения у пациентов с артериальной гипертензией: обзор литературы и собственный опыт \\ В.А. Скибчик, А.С. Пелешко}

Резюме. В статье обобщены данные ряда эпидемиологических исследований по проблеме взаимосвязи между артериальной гипертензией (АГ) и когнитивными нарушениями, деменцией. В собственном исследовании установлено, что наличие АГ достоверно повышает частоту развития когнитивных нарушений у лиц среднего возраста (49,8 9, 0 года). Обследовано 59 больных (1-я группа) с АГ II-III стадии, 2-3 степени (средний уровень систолического и диастолического давления - $166 \pm 13$ и 97士6 мм соответственно). Во 2-ю группу вошли 30 практически здоровых лиц соответствующего возраста с нормальным уровнем артериального давления Для изучения когнитивных нарушений применяли нейропсихологические тесты: шкалу оценки когнитивных функций врачом общей практики (General Practitioner Assessment of Cognition - GPCOG), краткую шкалу оценки психического статуса (Mini-Mental State Examination - MMSE), таблицы Шульте. Анализ результатов показал достоверное ухудшение когнитивного статуса у больных 1 -й группы

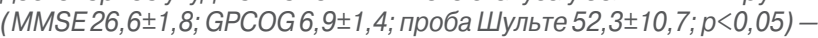
показатели, соответствующие легким и умеренным когнитивным нарушением. Во 2-й группе когнитивных расстройств не выявлено

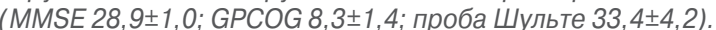

Ключевые слова: артериальная гипертензия, нейропсихологические тесты, когнитивные нарушения, деменция.

\section{Cognitive dysfunction and hypertension: literature review and own experience \\ V.A. Skybchyk, O.S. Peleshko}

Summary. The article summarizes available data linking arterial hypertension (AG) to cognitive dysfunction, dementia. In own study we also found that $A G$ significantly increases the incidence of cognitive dysfunction in middle-aged persons ( $49.8 \pm 9.0$ years). We selected 59 patients with AG of 2-3 degrees (the average level of systolic and diastolic blood pressure 166 \pm 13 and $97 \pm 6 \mathrm{~mm} \mathrm{Hg}$, respectively) ( $1^{\text {st }}$ group) and 30 practically healthy individuals with normal level of blood pressure ( $2^{\text {nd }}$ group). Neuropsychological examination was carried out by General Practitioner Assessment of Cognition(GPCOG), Mini-Mental State Examination(MMSE) and Schultetable. Significantcognitive decline was found in patients in the $1^{\text {st }}$ group (MMSE26.6 1.8 , GPCOG6.9 1.4 , Schulte's test52.3 $\pm 10.7 ; p<0.05)$. Such results correspond to mild and moderate cognitive dysfunction. There was no cognitive dysfunction in the $2^{\text {nd }}$ group

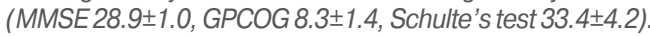

Key words: arterial hypertension, neuropsychological tests, cognitive dysfunction, dementia.

\section{Адреса для листування:}

Скибчик Василь Антонович

79031, Львів, вул. Стрийська, 292

Львівський національний медичний університет

імені Данила Галицького,

кафедра сімейної медицини ФпдО

E-mail: profvas292@gmail.com

Одержано 26.04.2019 